\title{
Measurement of attitudes in masculine organizational contexts
}

\author{
Rosa Monteiro ${ }^{1}$ \\ Amélia Filipa Soares Vieira ${ }^{2}$ \\ Fernanda Daniel ${ }^{12}$ \\ Alexandre Gomes da Silva ${ }^{31}$ \\ Fátima Regina Ney Matos ${ }^{2}$ \\ ${ }^{1}$ Universidade de Coimbra, Coimbra, Portugal \\ ${ }^{2}$ Instituto Superior Miguel Torga, Coimbra, Portugal \\ ${ }^{3}$ Instituto Superior de Contabilidade e Administração de Coimbra / Coimbra Business School, Coimbra, Portugal
}

Organizations developing equality plans must understand the persistence of workers' asymmetric conceptions based on gender stereotype. This study was conducted in Portugal and aimed to identify whether there are more gender stereotypes in highly masculinized organizational contexts. A questionnaire "Men's Polarized Gender Thinking Questionnaire (MPGQ)" was applied to a sample of 160 workers from two organizations: Águas Limpas and SOS. In the labor market, men with higher levels of education tend to present more equalitarian attitudes, while less educated men are less likely to recognize inequalities. Individuals' schooling and education are crucial, as these aspects stand out as important vectors for the acquisition of a more equalitarian system of beliefs and social values on the theme of gender relations. The results show that the attitudes of men towards gender equality are not distributed randomly. These findings corroborate the warningsmade in research adopting intersectionality approaches.

Keywords: horizontal segregation; (un)equalities; gender.

\section{Medida de atitudes em contextos organizacionais masculinos}

Compreender a persistência de concepções assimétricas assentes em estereotipia de gênero de trabalhadores é fundamental para as organizações que desejem desenvolver planos de gestão para a igualdade. O propósito deste estudo, realizado em Portugal, foi identificar se em contextos organizacionais altamente masculinizados, ou seja, majoritariamente masculinos, a estereotipia de gênero tende a ser mais acentuada. Para sua realização, aplicou-se o questionário "Men’s Polarized Gender Thinking (MPGQ)" a uma amostra de 160 trabalhadores de 2 organizações Águas Limpas e SOS. As participações no mercado de trabalho dos homens com níveis de instrução mais elevados se articulam com atitudes mais igualitaristas, ao passo que são os menos escolarizados que menos reconhecem as desigualdades. A escolarização e a educação dos indivíduos são consideradas fundamentais, pois se destacam como importante vetor de aquisição de um sistema de crenças e de valores sociais mais igualitários. Os resultados. Os resultados obtidos demonstram que as atitudes dos homens em relação à igualdade de gênero não se distribuem aleatoriamente. Esses achados corroboram alertas lançados pelas abordagens da interseccionalidade.

Palavras-chave: segregação horizontal; (des)igualdades; gênero.

\section{Medición de actitudes en contextos organizacionales masculinos}

Para entender la persistencia de concepciones asimétricas basadas en las estereotipias de género de los trabajadores, es fundamental que las organizaciones deseen desarrollar planes de gestión para la igualdad. El propósito de este estudio, realizado en Portugal, fue identificar si en contextos organizacionales altamente masculinizados la estereotipia de género tiende a ser más acentuada. Para su realización se aplicó el cuestionario Men’s Polarized Gender Thinking en una muestra de 160 trabajadores de dos organizaciones: Águas Limpas y SOS. La participación en el mercado de trabajo de los hombres con niveles más elevados de instrucción está vinculada con actitudes más igualitarias, mientras que los menos escolarizados son los que menos reconocen las desigualdades. La escolarización y educación de los individuos se consideran fundamentales, ya que se destacan como un vector importante para la adquisición de un sistema de creencias y valores sociales más igualitario sobre el tema de las relaciones de género. Los resultados obtenidos muestran que las actitudes de los hombres hacia la igualdad de género no se distribuyen aleatoriamente. Estos hallazgos corroboran las advertencias emitidas por los enfoques de interseccionalidad. Palabras clave: segregación horizontal; (des)igualdades; género. 


\section{INTRODUCTION}

In Portugal, despite formal and legal progress in the area of equality between women and men at work and employment (Monteiro, 2010), in reality numerous inequalities and even gender discrimination persist (Monteiro \& Ferreira, 2013; Ornelas, Matos, Ax, \& Mosque, 2017). According to Nogueira (2001), what persists, however, is the distance between formal and political legal equality and everyday practice. Rights and principles remained in the theoretical realm, especially in socioeconomic terms and with regard to women's private lives.

Thus, the spheres of work (paid and unpaid) and employment constitute ideal spaces for observing and transforming gender social relations, in their harmful consequences and their asymmetrical outcomes for each other. "Gender" is the term proposed by Ann Oakley to refer to the fact that, in relation to the biological differences between the two sexes, social and cultural meanings and assumptions are constructed about "feminine" and "masculine", about "being a woman" and "being a man", which impose themselves on social and individual cognitions, producing and reproducing gender stereotypes (Amâncio, 1992; Monteiro, 2005).

Gender stereotypes are widespread opinions or prejudices about attributes or characteristics that men and women have or should possess or the social functions they perform or should perform represent symbolic barriers, with impacts on organizational and management practices, limiting decisions and attributions based on a stereotypical idea of masculinity and femininity.

Sealy and Singh (2010) argue that organizational cultures are highly resilient to gender-friendly conceptions of male power, strongly resisting initiatives to promote equal opportunities. In turn, Broadbridge and Simpson (2011), understand that gender hierarchies are becoming stronger, facilitated by discourses of female equality and the primacy given to meritocracy and choice, particularly well-received rhetoric among younger generations of managers. However, the same authors highlight a set of factors that make these inequalities and asymmetries that must be addressed invisible.

As a result, the gender dimension has been hidden in work organizations and management studies, and made invisible by a neutral management ideology that is irrelevant to the achievements already achieved. As Broadbridge and Simpson (2011) point out, gender has historically been ignored or marginalized in mainstream management research, though increasingly integrated in the fields of human resource management, organizational behavior and leadership (overlooked in studies in the marketing, finance and production areas) (Broadbridge \& Hearn, 2008). This is due to three main reasons: because it is understood that the issues of inequality between women and men are "already resolved" and equality is already a reality (often deduced from the false evidence that women "are already everywhere") because today there is a focus on diversity management that dilutes the specific issue of gender (dis) equality; by the powerful discourse of meritocracy and personal choice that currently prevails in the field of management, with a special influence on younger generations of managers.

This discourse leads to the reinterpretation of gender disadvantages, especially women, not as a structural, institutional and cultural issue, but as a matter of personal choice (Broadbridge \& Simpson, 2011). Still for the first reason, the enhancement of "feminine qualities" in new management approaches, which highlights the importance of emotions, teamwork and communication, as well as 
programs for empowering women for management and leadership, created the view that "everything is already done" and that equality already exists.

In light of this, the need has been highlighted in the literature (European Agency for Safety and Health at Work, 2013; Broadbridge \& Simpson, 2011; Fagan \& Burchell, 2002) to make visible and conceptualize gender inequalities, but underestimated, in the work and organizations universe, expressed not only in management practices and the results achieved by men and women, but also in symbolic, cultural and identity dimensions of organizational life that influence those practices and results. For this reason, one of the research strategies proposed by Broadbridge and Simpson (2011) is intended to unravel the hidden aspects and the concealment of gender issues in the norms, practices and values present in organizations and organizational subjects, and to understand how genderized identities are constructed and maintained in different organizational contexts.

This was precisely the main purpose of this study: starting from the observation of a highly masculinized organizational context, we sought to identify whether, in highly segregated professional universes, gender stereotyping tends to be more pronounced. In addition to the painful social conceptions of gender for women and their professional affirmation, environments hostile to equality entail costs for organizations by excluding skills and human capital. As the study "The Athena Factor" (Hewlett et al., 2008) demonstrated, in the American science sector, new technologies and engineering, masculinized work and organizational cultures represent hostile environments that exclude and alienate professional women in a brain drain phenomenon - a phenomenon referring to the loss of capital / human resources with high levels of education.

This phenomenon is reported in the literature in association with the departure of professionals with higher education levels from less developed or hostile countries to more developed countries; In the context of this study, the phenomenon is extended to the loss of female capital / human resources - penalizing the sector itself, especially the private sector. A masculinized environment is one where men have a numerical majority, with horizontal segregation evidenced by the prevalence of stereotypically male tasks.

Other management studies consider it important to know the gender beliefs and attitudes of men employees as a way of enhancing the entry of women into traditionally masculinized sectors and to alter aspects of a male culture and structure in the workplace avoiding discrimination and inequality, especially among women (Bergman, Larsman, \& Löve, 2014; Smith, Crittenden, \& Caputi, 2012).

After this introduction, the theoretical framework is presented in the first part, explaining the analytical line that guides the study, the fundamental conceptions and conceptualizations for the analysis of the problem; Next, the methodology,sample characterization, data collection instruments and data analysis techniques are presented; Finally, in the third part, the discussion / conclusion is presented. 


\section{ORGANIZATIONS AND GENDER: HORIZONTAL SEGREGATION AND ORGANIZATIONAL CULTURES HOSTILE TO EQUALITY}

After decades of the idea of supposed management and organization neutrality, it has been shown that gender social relations are created and recreated in the work environment, not only by the actions of people, but also by the actions of organizations (Acker, 1990, 2009; Collinson, 1992; Fenstermaker, West, \& Zimmerman, 1991; Kanter, 1993; Morgan, 1992; Reskin \& Padavic, 1994).

Genderization of organizations is mentioned, a process defined as the material and discursive constructions of masculinity and femininity that shape and are shaped by the systems, work practices, norms and identities of organizations (Benschop \& Verloo, 2006).

Acker (2009) provided the most prominent contribution to this recognition by arguing that all organizations have "inequality regimes" defined as interrelated practices, processes, actions, and meanings that maintain class, gender, and racial inequalities within organizations.

Acker (1992) presents us with four levels of manifestation of these processes of genderization of organizations. The first corresponds to the production of gender divisions in organizational structures. This is expressed in segregation phenomena, such as, for example, the reduced presence of women in decision-making positions (known as vertical segregation, or glassceiling), or the existence of occupations predominantly occupied by one sex (horizontal segregation, or glasswalls). Although challenged by Crenshaw's intersectional approaches (1989), that challenge the assumption of a unitary and homogeneous subject underlying liberal feminisms, these concepts have strong heuristic power when it comes to analyzing cultural processes such as those underlying the gendered conceptions produced and reproduced by the subjects and in organizations. The second level concerns the presence of symbolic representations of masculinity and femininity in organizational cultures, which is expressed more or less latently. Gender stereotypes are symbolic barriers, with impacts on organizational and management practices, conditioning decisions and attributions based on a stereotyped idea of masculinity and femininity. One of these impacts is clearly visible, for example, in the barriers to paternity rights of male workers, as demonstrated by Lopes (2009). Another level corresponds to the processes of social interaction that mark the life of organizations and the men and women who work in them. Indeed, and as several studies have shown, social interaction in work organizations has a gender mark (Monteiro, 1995; Reskin \& Padavic, 1994). Finally, the fourth, more microanalytical, but extremely relevant, level is that which lies in the stratum of the organizational subject and his identity as a sexualized person, carrying experiences, conceptions and practices that produce and reproduce gender social relations. Fenstermaker et al. (1991) designated this process as doing gender.

The importance of workers' cognitions and gender representations in organizations also is mentioned by Fagenson (1990). The author understands that the behaviors of people in work organizations are gendered, that is to say, products and producers of gender conceptions, and this determines their rationalities, their thoughts, their options and their practices. Thus, globally, according to the author, human behavior in organizations should be studied as an articulated product of individual characteristics, the situation (organizational culture) and the more global institutional and social system, all determined by gender conceptions. Such conceptions condition the way people represent themselves and how they represent others in different contexts and life spheres, but also 
the concrete practices of and at work that they adopt, for example, and thus they must be considered by management.

Horizontal segregation, a concept that illustrates the stereotyping of the most appropriate professions for one sex, resulting in their professional and sectoral concentration, is one of the most visible consequences of gender conceptions in organizations and at work.

Studies have shown the special impact of occupational segregation in determining sexist and hostile environments for equality between women and men.

Hewlett et al. (2008) developed a study, funded by five major North American multinational companies (Alcoa, Cisco, Johnson \& Johnson, Microsoft, and Pfizer) to understand brain drain in the science, engineering, and technology sector in the United States of America (USA). The report, published by the Center for Work-Life Policy, New York, entitled The Athena Factor: Reversing the Brain Drain in Science, Engineering, and Technology (Hewlett et al., 2008), reports the problem of shortage of skilled workers in companies in the scientific sector, by about $52 \%$ of women aged 35-40 who are leaving their jobs in the sector due to "hostile work environments and strong professional pressures".

According to the report, the chauvinist culture excludes women from decision-making spaces - the after hours in the labs, bars or golf courses - depriving women of vital information. Exclusion is not only physical, but also acts through derogatory and humiliating behaviors and harsh, vulgar and even sexually explicit language, which further isolate women in these settings (63\% described situations of sexual harassment). According to the women studied, such behaviors are excused and even mimicked by the very leadership of companies. As one of the interviewees confessed, this is the response she got from the human resources department after complaining about these situations: "this way you will not succeed; you have to work harder to become one of the boys" (Hewlett et al., 2008, p. 7).

Five major reasons are mentioned for the departure of women: hostile male cultures; women's isolation and lack of support and mentoring; Mysterious career models, due to isolation and lack of counseling, many feel "stagnant", unsure how to direct their professional betting; risk and reward systems in which women feel helpless and therefore tend to fear taking risks; and high professional pressure due to the culture of very intensive hours (Hewlett et al., 2008).

Careers (2004) extensively studied the integration of women in the Portuguese armed forces, detecting the resistance and maintenance of the organizational structures of the military organization, despite the entry of women. These studies and their conclusions recall the findings of Rosabeth Moss Kanter's seminal work Men and Women of the Corporation (1993), although it only considered an explanatory factor for the difference between women and men and organizational structures (opportunities for promotion, power and organizational resources and the numerical proportion of men and women in hierarchical positions) and neglected dominant and stereotyped gender conceptions. However, her work was fundamental in the field of management as it removed the individual characteristics of women as explanatory factors of discrimination and exclusion.

One of the most studied and widespread components of his theory is that which equates the numerical disproportion of men and women in the same context, understanding that such disproportion penalizes the minority group. Members of the minority group, women, in the case of 
masculinized environments, are seen as tokens, representatives of this category, and not as independent individuals, which exacerbates stereotypy.

These seminal approaches in gender and organizational studies are challenged by the introduction of the intersectional perspective by rejecting the conception of a unitary and homogeneous subject and introducing the relationship between identity and power. Crenshaw (1989) presents it as a lens that allows us to see where power is and where the axes of inequality converge. Let us remember that the author developed the concept in the 1980s from the case of a black woman who had been discriminated against during access to employment. This woman's complaint was not answered by the court because the company alleged that it hired black individuals and women. However, all the black individuals recruited by the company were men (factory workers) and all the women were white (office workers). Such an approach has inspired new research and conceptualizations that interprets women's position in organizations not only in terms of exclusion from the dominant male norm, but also in the way women and reconfigured femininities are being included in contemporary workplaces (Lewis, 2014).

It is also worth mentioning the work of Calás and Smircich (2011), which problematize from a poststructuralist and postcolonial feminist perspective, approaching genderization in an interactional perspective and studying subjectivities, subject positions and institutions as temporal processes and spaces that are the product and producers of transnational processes. In his perspective, it is the intersection of sex with race, ethnicity, class, sexuality, and other subjectivities that makes it possible to fully understand the global processes of inequality. Not denying its heuristic importance, the approach seems to us to be of less use in this research focusing on gender stereotyping and its manifestation in the beliefs and attitudes of the surveyed male workers (of various socioeconomic groups and educational attainment, of course).

\section{THE SOCIAL ROLE OF GENDER}

Gender conceptions, which determine "who does what" based on "what women are like" and "what men are like", are normative and impose on the definition of different capacities, roles and functions between women and men (Monteiro, 2005). As stated by Acker (1992), the idea of the "ideal worker", who continuously works all the time, has been postulated, assuming that he has the backing of a partner who takes on family work (Lewis \& Cooper, 1995), clearly influenced by the Parsonian family model, in which the man is the "provider" and the woman is the "caregiver". The strength of this stereotype that conditions social gender roles in work, family, political and civic life is present both in the cognitions of individuals (men and women) and in the models of functioning and management of work organizations. According to Aboim (2007) and Wall, Aboim and Cunha (2010), the discourse persists in a conservative pro-natalist and familialist policy of sending women back to the home and domesticity. With regard to women's social position and their roles, attitudes are more conservative, highlighting an opposition between an ideal of female mother and housewife and the ideal of independent woman (Aboim, 2007, 2010).

Regarding attitudes and values, the authors report that the traditional male breadwinner model has been weakening in Portugal more than in other countries, due to the predominance of the double salary model. Aboim (2010, p. 64) states that "men move away from the traditional role of provider and 
authoritarian man, usually absent from domestic and parental daily life, praising male participation, presence and cooperation in the family". In Portugal, in parallel with the high rates of male activity, women's activity and employment rates have increased sharply since the late 1960s, reducing the numerical gap between men and women in the labor market.

This evolution led to a transformation of the family organization itself, with the predominance of the male breadwinner model of the past giving way to double employment. Such a reorganization of the roles of men and women in the family challenged the traditional archetype of masculinity, highlighting today the spread of a caring masculinity, already clearly less structured due to the role of provider (Wall et al., 2010). There is strong evidence in Portugal attesting to the lack of social sensitivity and poor recognition of gender-based inequalities, and even disregard for legislative achievements and these "new" ideas and claims about masculinity (Ferreira et al., 2007).

Other studies report increased psychosocial risks for women in masculine professional settings (Bergman, 2003), increased exposure to stress and sexual harassment (Parker \& Griffin, 2002), difficulties regarding career advancement (Crawford \& Unger, 2004), exclusion from information networks, disregarding women's opinions and ideas in meetings (Janz \& Pyke, 2000).

Diagnosis that are sensitive to gender social relations is therefore essential as a tool for making asymmetries visible and intervention for change. Diagnostics and studies should provide management and decision-makers with structural indicators that reflect the presence and manifestation of gender inequalities and discrimination (e.g horizontal and vertical segregation), as well as the main difficulties in reconciling and using the rights of people in the organization; the values and gender representations of people linked to the organization, the conceptions of sexual roles and the stereotypes that determine their experiences and constrain their cognitions, options and activities (Monteiro \& Ferreira, 2013).

To understand gender attitudes and conceptions,studies have provided tools for measuring more manifested (Spence, Helmreich, \& Stapp, 1975) or more latent forms of sexism (Swim \& Cohen, 1997), as well as models of interventions to combat it. (Zawadzki, Shields, Danube, \& Swim, 2014).

Swim and Hyers (2009, p. 407) define sexism as "individual attitudes, beliefs, and behaviors, as well as organizational, institutional, and cultural practices that reflect negative assessments of individuals based on their gender and favor differences in the status of men and women." Swim and Cohen's (1997) Modern Sexism Scale (MS), for example, measures subtle forms of sexism. This measure complemented an instrument dating back to the 1970s, the Attitudes Toward Women Scale (AWS), which measured explicit forms of sexism (Spence et al., 1975).

In Portugal, the evolution of gender attitudes has been studied, showing ambivalence, since it hangs between the two poles of values, a modernist and individualizing and another traditionalist and familialist (Aboim, 2007, 2010; Monteiro, Agostinho , \& Daniel, 2015; Torres, Coelho, Jerónimo, \& Cabrita, 2009). According to the conclusions of the project "Working and Caring for Europe", and in terms of gender roles, Portugal, despite finding affinities with more "traditionalist" countries, is the "intermediate" type (Torres et al., 2009).

There has been evolution in the family model of double salary and destitution of the male breadwinner model, however, regarding the social position of women and their roles linked to 
domesticity and motherhood, some conservatism is still manifested (Aboim, 2010). The decline of the male breadwinner model leads to changes in women's social place and also to the model of masculinity, reconfiguring men's identities and social roles in the various spheres of life; For this reason, men themselves have been the object of analysis and potential agents of change (Hearn et al., 2002).

\section{METHODOLOGICAL PROCEDURES}

The starting point for this research came from a study performed in Sweden, in which it was possible to develop a new measure of gender equality in mostly male workplaces, enabling quantitative analysis of male beliefs about gender inequality at work. Based on the finding that there was insufficient research on men's opinions on the reasons for inequalities at the organizational level and that it could be relevant to create an inventory to measure men's attitudes about gender equality at work, Bergman et al. (2014) developed the "Men's Polarized Gender Thinking Questionnaire (MPGQ)" questionnaire, adopted in this research. The study began with a qualitative interview survey conducted in 3 masculinized work environments (Bergman, 2008), where the category "gender polarized thinking" was created, which describes the coexistence of opposite and paradoxical feelings and practices in a polarization between positive and negative perspectives. That is, if on the one hand expectations emerged that women should adjust to existing "male rules", on the other hand, gender equality was also envisaged as a possible reality in the organization's future practices. This led to the creation of 2 analytical categories: Illusory gender equality and visualizing and practicing gender equality. From the construction of the questionnaire and various validation procedures, a 23-item scale and an explanatory model consisting of 6 factors were constructed: a) Different views on success; b) Gender stereotyped roles; c) benevolent sexism; d) Gender awareness; e) Awareness of the male standards system; and f) Strategies for gender equality.

The procedures for obtaining the Portuguese version of MPGQ, the result of which is presented here, were based on the translate - translate back method (Hill \& Hill, 2002). The Portuguese and English language versions showed a high degree of similarity, confirming the equivalence between the original and the translated version (Hambleton, Merenda, \& Spielberger, 2005; International Test Commission, 2017). In a second phase, gender specialists who were simultaneously fluent researchers in the English language were called upon; analyzing the content of the questionnaire, the final version was validated.

A small sociodemographic questionnaire was also constructed which was to be applied to male workers from two organizations. The study was conducted at a municipal water supply and treatment company (to preserve anonymity, we named the company "Águas Limpas", which has a staff of 270 people, $75 \%$ of whom are men) and in a public entity, in the emergency medical sector in the central region (which we call "SOS", with 250 people in service, 67\% of whom are men). The sample had a total of 160 male workers, corresponding to $30.7 \%$ of the total universe of both organizations. In terms of age, the highest concentration of men corresponds to the age group of 30 to 39 years (46.9\%); $49.9 \%$ of workers have a level of education corresponding to the 12 th grade. The vast majority of men (69.4\%) are married or are in a stable union relationship. With regard to 
length of service in the organization, $37 \%$ of workers are employed by their respective organizations for periods ranging from 5 to 9 years.

Respondents were instructed to respond between the "completely disagree" (lowest point of the scale) and "completely agree" points (the highest point of the scale). The questionnaires were applied at Águas Limpas in June and July 2016, while at SOS the same application took place in November 2016. Participation was voluntary and data confidentiality and anonymity were ensured.

After applying and collecting the questionnaires, the data were processed using SPSS software, version 21.0.

\subsection{Statistical Analysis}

We started the study of the scale by observing the internal consistency (Cronbach's alpha) of the items that compose the MPGQ. Next, a factor analysis was performed to explore the underlying structure of the items that make up the subscale. The main objective of this analysis is to reduce the complexity of the interrelationships between the 23 variables observed in a relatively small number of linear combinations with such variables. At first, the adequacy of the data to this type of statistical procedure was verified, considering the sample size and the strength of the relation between the items. To determine the number of principal components to be retained, both the Kaiser criterion (eigenvalue equal to or greater than 1) and Cattell's (scree plot) distribution were observed. The application of these criteria aimed to obtain an indication of the minimum number of latent factors to be retained that would be able to summarize the information appropriately and thus explain a considerable proportion of the total variance.

In the univariate description of the variables, measures of central tendency (mean and median) and dispersion (standard deviation) were used. In the analysis of differences between the score of the scale items and the sociodemographic and professional variables, the Mann-Whitney $U$ test (nonparametric test that compares the distribution functions of at least one ordinal level of measurement in 2 independent samples) and Kruskal-Wallis $\mathrm{H}$ (test comparing the distributions of 2 or more at least ordinal variables observed in 2 or more independent samples) were used. A significance level of $\mathrm{p} \leq$ 0.05 was considered as indicating the existence of statistically significant differences between group order averages.

\section{RESULTS}

Cronbach's alpha calculation revealed that the MPGQ questionnaire presents adequate internal consistency $(\alpha=0.77)$, respecting the recommended values (Peterson, 1994; Daniel, Gomes \& Ferreira, 2015).

Then, an exploratory factor analysis was performed to analyze the dimensional structure of the MPGQ. In this study, the indication of the use of the factor model in the MPGQ analysis was reinforced by a $0.81 \mathrm{KMO}$ (the closer to 1 , the greater the appropriateness of a factor analysis) and a Bartlett test with a lower significance level at 0.001 . The latter leads to the rejection of the hypothesis that the correlation matrix in the population is the identity matrix, showing that the existing 
correlation occurs between the variables (Pestana \& Gageiro, 2008). In order to verify if the MPGQ items saturate the factors described in the original scale, an exploratory factor analysis was carried out using the principal components method to determine the contributions from each item to each factor. Exploratory factor analysis lead to, as in the original scale, 6 factors with values greater than 1 that cumulatively explain $61 \%$ of the variance. However, the results obtained were not identical to those of the original scale study. There was no agreement of the items belonging to the factors and 7 items saturate in more than 1 factor (crossloadings).

Given the results, the analysis was performed item by item. To verify if there were differences between the scores of the different items of the scale, according to the literature qualifications, the Kruskal-Wallis $\mathrm{H}$ test was performed. The variables that presented significance level of $\mathrm{p}<0.05$ are shown in Table 1. Thus, it can be seen that the variables "Professional career is more important for men than for women" and "For men it is more important to support the family than the parental role "(Different views on success) present statistically significant differences according to the qualifications of the literature $(\mathrm{x} 2(4, \mathrm{n}=155)=10,263, \mathrm{p}=0.036, \mathrm{x} 2(4, \mathrm{n}=155)=10,878$, $\mathrm{p}=0.028$, respectively). In these variables, the group with the lowest level of qualifications in the literature presents higher median and average $(\mathrm{Md}=2$ and $\mathrm{M}=2.46, \mathrm{Md}=3$ and $\mathrm{M}=2.77$, respectively).

The variables "Women are more hesitant to expose their potentials (competencies) than men", "When it comes to negotiating wages, men are stronger at demanding than women" and "Men usually talk to each other more abrupt when there is no woman present "also presented significance level of $\mathrm{p}<0.05(\mathrm{x} 2(4, \mathrm{n}=155)=15.904, \mathrm{p}=0.003, \mathrm{x} 2(4, \mathrm{n}=155)=15.598, \mathrm{p}=0.004, \mathrm{x} 2$ $(4, \mathrm{n}=155)=25.012, \mathrm{p}<0.001$, respectively $)$ and it is the people with lower educational attainment who have the highest scores $(\mathrm{Md}=3$ and $\mathrm{M}=2.77, \mathrm{Md}=3$ and $\mathrm{M}=3,38 \mathrm{Md}=3$ and $\mathrm{M}=3.15$, respectively).

Regarding the variable "Women in leadership positions give more support to their workers than men in leadership positions", we find that it is men who have the 9th grade who have the highest score on the trend level central $(\mathrm{Md}=3$ and $\mathrm{M}=2.75) \times 2(4, \mathrm{n}=155)=18.943, \mathrm{p}=0.01)$. The variable "People, in general, pay more attention to what men say" shows that it is the group with the lowest level of qualification that has the highest score $(\mathrm{Md}=3$ and $\mathrm{M}=2.62) \mathrm{x} 2(4, \mathrm{n}=155)=12.577$, $\mathrm{p}=0.014)$. Regarding the variable "Women are usually assigned different tasks than men" are the groups with the lowest level of qualifications that have higher scores and the difference is only 6 tenths, with an advantage for the 9th grade group. $(M d=3$ and $M=3.06) \times 2(4, n=155)=19.788$, $\mathrm{p}=0.001$ ). The higher end of qualifications (masters) has the highest score, both in the variable "Equality between men and women in the workplace is still far from being achieved" and in the variable "Increasing the number of women in this organization, will only be achieved if management takes action accordingly" $(\mathrm{Md}=3$ and $\mathrm{M}=3.00) \times 2(4, \mathrm{n}=155)=9.701, \mathrm{p}=0.046 \mathrm{e}(\mathrm{Md}=3$ and $\mathrm{M}=2,80) \times 2(4, \mathrm{n}=155)=19.265, \mathrm{p}=0.001)$. 


\section{TABLE 1 MEASURES OF CENTRAL TENDENCY AND DISPERSION (M, MD AND DP) AND SIGNIFICANCE VALUES OF MPGQ ITEMS ACCORDING TO QUALIFICATIONS}

\begin{tabular}{|c|c|c|c|c|c|c|}
\hline & $<9^{\circ}$ & $9^{\circ}$ & $12^{\circ}$ & Lic. & Mest. & \\
\hline & $n=13$ & $n=16$ & $n=79$ & $n=42$ & $n=5$ & $P$ \\
\hline I - Different views on success & $\begin{array}{c}M \pm D P \\
(M d)\end{array}$ & $\begin{array}{c}M \pm D P \\
(M d)\end{array}$ & $\begin{array}{c}M \pm D P \\
(M d)\end{array}$ & $\begin{array}{c}M \pm D P \\
(M d)\end{array}$ & $\begin{array}{c}M \pm D P \\
(M d)\end{array}$ & \\
\hline $\begin{array}{l}\text { Professional career is more important to } \\
\text { men than women }\end{array}$ & $\begin{array}{c}2.46 \pm 1.13 \\
\text { (2) }\end{array}$ & $\begin{array}{c}1.69 \pm 1.01 \\
(1)\end{array}$ & $\begin{array}{c}1.65 \pm 0.79 \\
\text { (1) }\end{array}$ & $\begin{array}{c}1.45 \pm 0.55 \\
\text { (1) }\end{array}$ & $\begin{array}{c}1.40 \pm 0.55 \\
\text { (1) }\end{array}$ & 0.036 \\
\hline $\begin{array}{l}\text { For men it is more important to support } \\
\text { the family than the parental role }\end{array}$ & $\begin{array}{c}2.77 \pm 0.60 \\
\text { (3) }\end{array}$ & $\begin{array}{c}2.44 \pm 0.81 \\
(2.5)\end{array}$ & $\begin{array}{c}2.24 \pm 0.82 \\
(2)\end{array}$ & $\begin{array}{c}2.07 \pm 0.75 \\
\text { (2) }\end{array}$ & $\begin{array}{c}1.80 \pm 0.84 \\
\text { (2) }\end{array}$ & 0.028 \\
\hline \multicolumn{7}{|l|}{ II - Stereotyped gender roles } \\
\hline $\begin{array}{l}\text { Women are more hesitant to expose their } \\
\text { potential (skills) than men }\end{array}$ & $\begin{array}{c}2.77 \pm 0.44 \\
\text { (3) }\end{array}$ & $\begin{array}{c}2.31 \pm 0.70 \\
(2)\end{array}$ & $\begin{array}{c}2.03 \pm 0.68 \\
(2)\end{array}$ & $\begin{array}{c}2.10 \pm 0.66 \\
\text { (2) }\end{array}$ & $\begin{array}{c}2.20 \pm 0.45 \\
\text { (2) }\end{array}$ & 0.003 \\
\hline $\begin{array}{l}\text { When it comes to negotiating wages, } \\
\text { men are stronger to demand than women }\end{array}$ & $\begin{array}{c}3.38 \pm 0,51 \\
\text { (3) }\end{array}$ & $\begin{array}{c}3.13 \pm 0.72 \\
\text { (3) }\end{array}$ & $\begin{array}{c}2.71 \pm 0.80 \\
\text { (3) }\end{array}$ & $\begin{array}{c}2.64 \pm 0.82 \\
\text { (3) }\end{array}$ & $\begin{array}{c}3.20 \pm 0.45 \\
\text { (3) }\end{array}$ & 0,004 \\
\hline $\begin{array}{l}\text { Men usually talk more abruptly when } \\
\text { there is no woman present }\end{array}$ & $\begin{array}{c}3.15 \pm 0.56 \\
\text { (3) }\end{array}$ & $\begin{array}{c}2.63 \pm 0.89 \\
(2,5)\end{array}$ & $\begin{array}{c}2.05 \pm 0.80 \\
\text { (2) }\end{array}$ & $\begin{array}{c}2.14 \pm 0.57 \\
\text { (2) }\end{array}$ & $\begin{array}{c}2.20 \pm 0.84 \\
\text { (2) }\end{array}$ & $<0,001$ \\
\hline \multicolumn{7}{|l|}{ III - Benevolent Sexism } \\
\hline $\begin{array}{l}\text { Women in leadership positions give more } \\
\text { support to their workers than men in } \\
\text { leadership positions }\end{array}$ & $\begin{array}{c}1.83 \pm 0,39 \\
(2)\end{array}$ & $\begin{array}{c}2.75 \pm 0.68 \\
\text { (3) }\end{array}$ & $\begin{array}{c}2.01 \pm 0.64 \\
\text { (2) }\end{array}$ & $\begin{array}{c}2.00 \pm 0.54 \\
\text { (2) }\end{array}$ & $\begin{array}{c}1.80 \pm 0.45 \\
\text { (2) }\end{array}$ & 0.001 \\
\hline \multicolumn{7}{|l|}{ IV - Gender Awareness } \\
\hline $\begin{array}{l}\text { People in general pay more attention to } \\
\text { what men say }\end{array}$ & $\begin{array}{c}2.62 \pm 0.77 \\
\text { (3) }\end{array}$ & $\begin{array}{c}2.25 \pm 0.78 \\
(2)\end{array}$ & $\begin{array}{c}2.19 \pm 0.74 \\
\text { (2) }\end{array}$ & $\begin{array}{c}1.86 \pm 0.61 \\
\text { (2) }\end{array}$ & $\begin{array}{c}2.20 \pm 0.84 \\
\text { (2) }\end{array}$ & 0.014 \\
\hline $\begin{array}{l}\text { Women are often assigned different } \\
\text { tasks than men }\end{array}$ & $\begin{array}{c}3.00 \pm 0.58 \\
\text { (3) }\end{array}$ & $\begin{array}{c}3.06 \pm 0.44 \\
\text { (3) }\end{array}$ & $\begin{array}{c}2.51 \pm 0.78 \\
\text { (3) }\end{array}$ & $\begin{array}{c}2.62 \pm 0.70 \\
\text { (3) }\end{array}$ & $\begin{array}{c}1.60 \pm 0.55 \\
\text { (3) }\end{array}$ & 0.001 \\
\hline \multicolumn{7}{|l|}{$\begin{array}{l}V \text {-Awareness of the male standards } \\
\text { system }\end{array}$} \\
\hline $\begin{array}{l}\text { Equality between men and women in the } \\
\text { workplace is still far from being achieved. }\end{array}$ & $\begin{array}{c}2.54 \pm 1.05 \\
\text { (3) }\end{array}$ & $\begin{array}{c}2.69 \pm 0.60 \\
\text { (3) }\end{array}$ & $\begin{array}{c}2.24 \pm 0.84 \\
\text { (2) }\end{array}$ & $\begin{array}{c}2.24 \pm 0.79 \\
\text { (2) }\end{array}$ & $\begin{array}{c}3.00 \pm 0.71 \\
\text { (3) }\end{array}$ & 0.046 \\
\hline \multicolumn{7}{|l|}{ VI - Strategies for gender equality } \\
\hline $\begin{array}{l}\text { Increasing the number of women in } \\
\text { this organization, will only be achieved } \\
\text { if management takes steps in this } \\
\text { direction. }\end{array}$ & $\begin{array}{c}2.62 \pm 0.77 \\
\text { (3) }\end{array}$ & $\begin{array}{c}2.69 \pm 0.80 \\
\text { (3) }\end{array}$ & $\begin{array}{c}1.96 \pm 0.78 \\
\text { (2) }\end{array}$ & $\begin{array}{c}2.17 \pm 0.73 \\
\text { (2) }\end{array}$ & $\begin{array}{c}2.80 \pm 0.84 \\
\text { (3) }\end{array}$ & 0.001 \\
\hline
\end{tabular}

Source: Elaborated by the authors. 
The Mann-Whitney U test was used to verify if there were differences between the scores of the different items of the scale according to the institutions where they work. The variables that presented significance at the level of $\mathrm{p}<0.05$ are shown in Table 2. Thus, we can see that the variables "Professional career is more important for men than for women" and "Men consider more than women that salary is an important measure of your professional success "(Different views on success) have statistically significant differences depending on the institutions where they work $(U=2272,000, z=-2,834$, $\mathrm{p}=0.005, \mathrm{U}=7501,500, \mathrm{z}=-2.039, \mathrm{p}=0.041$, respectively).

Aguas limpas employees have higher average scores $(\mathrm{Md}=2$ and $\mathrm{M}=1.90, \mathrm{Md}=2$ and $\mathrm{M}=2.32$, respectively). The Three Variables "committed" to gender stereotyping "Women are more hesitant to expose their potentials (competencies) than men", "Men usually talk more abruptly when there are no women present" and "When trying to negotiate wages, men are stronger in relation to demanding than women "also have higher scores in Águas Limpas $(\mathrm{Md}=2$ and $\mathrm{M}=2.32, \mathrm{Md}=3$ and $\mathrm{M}=2.60$, $\mathrm{Md}=3$ and $\mathrm{M}=2.60),(\mathrm{U}=2306,500, \mathrm{z}=-2.714, \mathrm{p}=0.007, \mathrm{U}=2312,000, \mathrm{z}=-2.733, \mathrm{p}=0.006$, respectively). The last two variables that were statistically significant are "To increase the number of women here in the organization, this will only be achieved if management takes action in this direction" and "It is more important to give more active support to women in managerial positions than men in managerial positions " $(\mathrm{U}=1770,500, \mathrm{z}=-4,544, \mathrm{p}<0.001, \mathrm{U}=2286,000, \mathrm{z}=-2,661$, $\mathrm{p}=0.008$ ), both have higher average scores in Aguas Limpas ( $\mathrm{Md}=3$ and $\mathrm{M}=2.55, \mathrm{Md}=2$ and $\mathrm{M}=2.58$, respectively).

\section{TABLE 2 MEASURES OF CENTRAL TENDENCY AND DISPERSION (M, MD AND SD) AND SIGNIFICANCE VALUES OF THE MPGQ ITEMS ACCORDING TO THE WORK INSTITUTION}

\begin{tabular}{|c|c|c|c|}
\hline & $\begin{array}{c}\text { Águas limpas } \\
\quad n=42\end{array}$ & $\begin{array}{l}\text { SOS } \\
n=5\end{array}$ & $P$ \\
\hline I - Different views on success & $\begin{array}{c}M \pm D P \\
(M d)\end{array}$ & $\begin{array}{c}M \pm D P \\
(M d)\end{array}$ & \\
\hline Professional career is more important to men than women & $\begin{array}{l}1.90 \pm 0.90 \\
(2)\end{array}$ & $\begin{array}{l}1.52 \pm 0.72 \\
(1)\end{array}$ & 0.005 \\
\hline $\begin{array}{l}\text { Men consider more than women that pay is an important measure of } \\
\text { their professional success. }\end{array}$ & $\begin{array}{l}2.32 \pm 0.98 \\
\quad(2)\end{array}$ & $\begin{array}{l}1.99 \pm 0.84 \\
(2)\end{array}$ & 0.041 \\
\hline \multicolumn{4}{|l|}{ II-Stereotyped gender roles } \\
\hline Women are more hesitant to expose their potential (skills) than men & $\begin{array}{l}2.32 \pm 0.65 \\
(2)\end{array}$ & $\begin{array}{l}2.03 \pm 0.67 \\
(2)\end{array}$ & 0.007 \\
\hline Men usually talk more abruptly when there is no woman present & $\begin{array}{l}3.02 \pm 0.75 \\
\text { (3) }\end{array}$ & $\begin{array}{l}2.68 \pm 0.79 \\
\text { (3) }\end{array}$ & $<0.001$ \\
\hline $\begin{array}{l}\text { When it comes to negotiating wages, men are stronger to demand } \\
\text { than women }\end{array}$ & $\begin{array}{l}2.60 \pm 0.81 \\
\text { (3) }\end{array}$ & $\begin{array}{l}2.01 \pm 0.70 \\
(2)\end{array}$ & 0.006 \\
\hline
\end{tabular}




\begin{tabular}{|c|c|c|c|}
\hline & $\begin{array}{l}\text { Águas limpas } \\
\quad n=42\end{array}$ & $\begin{array}{l}S O S \\
n=5\end{array}$ & $P$ \\
\hline \multicolumn{4}{|l|}{ VI - Strategies for gender equality } \\
\hline $\begin{array}{l}\text { Increasing the number of women here in the organization, will only be } \\
\text { achieved if management takes steps in this direction. }\end{array}$ & $\begin{array}{l}2.55 \pm 0.77 \\
\text { (3) }\end{array}$ & $\begin{array}{l}1.94 \pm 0.75 \\
(2)\end{array}$ & $<0.001$ \\
\hline $\begin{array}{l}\text { It is more important to give more active support to women in } \\
\text { managerial positions than men in managerial positions. }\end{array}$ & $\begin{array}{l}2.58 \pm 2.67 \\
\quad(2)\end{array}$ & $\begin{array}{l}1.96 \pm 0.67 \\
(2)\end{array}$ & 0.008 \\
\hline
\end{tabular}

Source: Elaborated by the authors

\section{DISCUSSION / CONCLUSIONS}

The existence of conceptions informed by the social representations of gender was verified in the analysis of the statistical data.

Based on the results, it was possible to reach the following conclusions: Regarding the significant differences found regarding the qualifications of the literature, it was noticeable that most men with low levels of education agree with the most conservative items. These items essentially reveal that the role of man goes through the traditional gender model that assigns men the role of provider and women the role of caregiver of the family. They also reveal that men consider the profession to be more important to men than women.

On the other hand, there is also an attitude of greater awareness of the still existing inequalities in the workplace and of the need for specific intervention by men with higher education, regarding the following items: "To increase the number of women in this organization will only be achieved if management takes action in that direction "and" Equality between men and women in the workplace is still far from being achieved".

These results demonstrate that men's attitudes toward gender equality are not randomly distributed. Participation in the labor of men with higher levels of education are connected to more egalitarian attitudes. The schooling and education of individuals are considered fundamental, as they stand out as an important vector for the acquisition of a more egalitarian system of beliefs and social values on the theme of the relationship between the sexes. These findings corroborate warnings issued by intersectionality approaches.

These data confirm the findings of other research regarding the persistence of traditionalist gender values. In fact, there has been appreciation and emphasis of motherhood and child care on female identity, while men are given greater appreciation regarding professional activity. This finding proves the ambivalence and dichotomy of values and attitudes, despite an escape from the conventional polarization of rigid and stereotypically defined "masculine" and "feminine" roles, also found in other studies in Portugal - a reflection of the evolution towards the "double salary"(Aboim, 2010).

In investigations on the production of social relations of gender, man was much more recently equated as an object of study, when it was realized that the traditional model of masculinity was changing (Almeida, Ferreira, Ferrão, \& André, 1995; Amâncio, 1994; Brod \& Kaufman, 1994; Kimmel 
\& Messner, 1995) and that work-family tension also applied to it (Crompton, 1999). If the maintenance of inequalities between men and women in the family sphere is undoubted, it is certain that there is also a movement of men's entry into the universe of domestic and parental production (Almeida \& Wall, 2001; Perista, 2002; Torres, 2001; Wall, 2005).

The main objective of gender equality policies is to achieve equal opportunities between women and men, but also results. According to Sörlin, Ohman, Blomstedt, Stenlund, and Lindholm (2011), the proportion of workers is a useful indicator overall, and it is reasonable to assume that a small number of women or men may be disadvantaged in an organization.

Another variable where significant differences were detected was related to the two institutions where this research was performed. With the support of the analysis of averages, it was concluded that in highly masculinized organizational contexts gender stereotyping tends to be more pronounced and that the employees of Águas Limpas are part of the most masculinized company, where roles are most stereotypically represented as "men", those in which the expression of differences based on social gender relations is superior to the less segregated organization. From this emerges a contribution of this research, proving that measures and policies to combat horizontal segregation have the potential to change gender stereotyping.

This study identified the perception of male workers from two organizations about gender inequalities. It is important to expand the application and testing of the instrument used to improve its measurement capability in the Portuguese context. More generally, this work contributes to the domain of gender and organizational studies, providing analytical tools for diagnostics and quantitative research demonstrating the phenomenon of genderization of organizations. 


\section{REFERENCES}

Aboim, S. (2007). Clivagens e continuidades de género face aos valores da vida familiar em Portugal e noutros países europeus. In K. Wall, \& Amâncio, L. (Eds.), Familia e género em Portugal e na Europa (pp. 35-91). Lisboa, Portugal: Imprensa de Ciências Sociais.

Aboim, S.(2010). A vida familiar no masculino: negociando velhas e novas masculinidades. Lisboa, Portugal: Comissão para a Igualdade no Trabalho e no Emprego.

Acker, J. (1990) Hierarchies, jobs, bodies: A theory of gendered organizations. Gender and Society, 4(2), 139-158. Retrieved from http://www.jstor.org/ stable/189609

Acker, J. (1992). Gendering organizational theory. In A. J. Mills, \& P. Tancred (Eds.), Gendering organizational analysis (pp. 248-260). Newbury Park, CA: SAGE.

Acker, J. (2009). From glass ceiling to inequality regimes. Sociologie du Travail, 51(2), 199-217.

Agência Europeia para a Segurança e Saúde no Trabalho. (2013). Risks and trends in the safety and health of women at work research. Luxembourg City, Luxembourg: Publications Office of the European Union.

Almeida, A. M. N., Ferreira, C., Ferrão, F., \& André, I. M. (1995). Os padrões recentes da fecundidade em Portugal. Lisboa, Portugal: Comissão para a Igualdade e para os Direitos das Mulheres.

Almeida, A. M. N., \& Wall, K. (2001). Família e quotidiano: movimentos e sinais de mudança. In J. B. Brito (Org.), O país em revolução (pp. 277-307). Lisboa, Portugal: Ed. Notícias.

Amâncio, L. (1992). As assimetrias nas representações do género. Revista Crítica de Ciências Sociais, 34, 9-22.

Amâncio, L. (1994). Masculino e feminino: a construção social da diferença. Porto, Portugal: Afrontamento.

Benschop, Y., \& Verloo, M. (2006). Sisyphus' sisters: can gender mainstreaming escape the genderedness of organizations? Journal of Gender Studies, 15(1), 19-33.
Bergman, B. (2003). The validation of the women workplace culture questionnaire: gender-related stress and health for Swedish working women. Sex Roles, 49, 287-297.

Bergman, B. (2008). Polarized gender balance: visions or norms in male-dominated work places? International Journal of Qualitative Studies on Health and Well-Being, 3(3), 165-175.

Bergman, B., Larsman, P., \& Löve, J. (2014). Psychometric evaluation of the "Men's Polarized Gender Thinking Questionnaire (MPGQ)". Gender in Management: An International Journal, 29(4), 194-209.

Broadbridge, A., \& Hearn, J. (2008). Gender and management: new directions in research and continuing patterns in practice. British Journal of Management, 19(1), 38-49.

Broadbridge, A., \& Simpson, R. (2011). 25 years on: reflecting on the past and looking to the future in gender and management research. British Journal of Management, 22(3), 470-483.

Brod, H., \& Kaufman, M. (Eds.). (1994). Theorizing masculinities. Thousand Oaks, CA: SAGE.

Calás, M.B. \& Smircich, L. (2011). From the 'Woman's Point of View' Ten Yeas Late: Toward a Feminist Organization Studies. In S.R. Clegg, C. Hardy, T.B. Lawrence \& W.R. Nord (Eds.) The SAGE Handbook of Organization Sudies (pp. 284-346). London: SAGE Publications. Retrieved from https:// doi.org/10.4135/9781848608030.n9

Carreiras, H. (2004). Mulheres em contextos atípicos: lógicas de exclusão e estratégias de integração feminina nas forças armadas. Etnográfica, 8(1), 91-115.

Collinson, D. (1992). Managing the shopfloor: subjectivity, masculinity and workplace culture. Berlin, Germany: Walter de Gruyter.

Crawford, M., \& Unger, R. (2004). Women and gender. A feminist psychology. New York, NY: McGraw-Hill.

Crenshaw, K. (1989). Demarginalizing the intersection of race and sex: a black feminist critique of antidiscrimination doctrine, feminist theory and antiracist politics. University of Chicago Legal Forum, 1, 139-167. 
Crompton, R. (Ed.). (1999). Restructuring gender relations and employment: the decline of the male breadwinner. Oxford, England: Oxford University Press.

Daniel, F., Gomes, A. \& Ferreira, P.L. (2015). Contributo para a discussão da avaliação da fiabilidade de um instrument de medição. Revista de Enfermagem Referência, 4(7), 129-137.

Fagan, C., \& Burchell, B. (2002). Gender, jobs and working conditions in the European Union. Dublin, Ireland: European Foundation for the Improvement of Living and Working Conditions.

Fagenson, E. A. (1990). At the heart of women in management research: theoretical and methodological approaches and their biases. Journal of Business Ethics, 9(4-5), 267-274.

Fenstermaker, S., West, C., \& Zimmerman, D. H. (1991). Gender inequality: new conceptual terrain. In R. Lesser-Blumberg (Ed.), Gender, family and economy: the triple overlap, 289-307. California: SAGE Publications. Retrieved from https://doi. org/10.4135/9781483325415.n14

Ferreira, V., Silveirinha, M. J., Portugal, S., Vieira, C., Monteiro, R., Duarte, M., \& Lopes, M. (2007). Estudo de avaliação do II Plano Nacional para a Igualdade. Coimbra, Portugal: Centro de Estudos Sociais.

Hambleton, R. K., Merenda, P. F., \& Spielberger, C. D. (2005). Adapting educational and psychological tests for cross-cultural assessement. Mahwah, NJ: L. Erlbaum.

Hearn, J., Pringle, K., Müller, U., Oleksy, E., Lattu, E., Tallberg, T., \& Olsvik, E. (2002). Critical studies on men in ten European countries: (3) The state of law and policy. Men and Masculinities, 5(2), 192-217.

Hewlett, S.A., Luce, C. B., Servon, L. J., Sherbin, L., Shiller, P., Sosnovich, E., \& Sumberg, K.(2008). The Athena Factor: reversing the brain drain in science, engineering, and technology. New York, NY: Center for Work-Life Policy.

Hill, M., \& Hill, A. (2002). Investigação por questionário (2 ed.). Lisboa, Portugal: Sílabo.

International Test Commission. (2017). ITC guidelines for translating and adapting tests (2 ed.).
Retrieved from https://www.intestcom.org/files/ guideline_test_adaptation_2ed.pdf

Janz, T. A., \& Pyke, S. W. (2000). A scale to assess student's perceptions of academic climates. The Canadian Journal of Higher Education, 30(1), 89-122.

Kanter, R. M. (1993). Men and women of the corporation. New York, NY: Basic Books.

Kimmel, M., \& Messner, M. (1995). Men's lives. Boston, MA: Allyn \& Bacon.

Lewis, P. (2014). Postfeminism, femininities and organization studies: exploring a new agenda. Organization Studies, 35(12), 1845-1866.

Lewis, S., \& Cooper, C. L. (1995). Balancing the work/home interface: a European perspective. Human Resource Management Review, 5(4), 289-305.

Lopes, M. (2009). Trabalho e parentalidade: um estudo sobre a acomodação ecustos da maternidade e paternidade para os índividuos e as organizações (Dissertação de Mestrado). Coimbra, Portugal: Universidade de Coimbra.

Monteiro, R. (1995). Feminilidade na fábrica: a (re)construção das identidades sexuais nas organizações de trabalho (Dissertação de Licenciatura). Coimbra, Portugal: Universidade de Coimbra.

Monteiro, R. (2005). O que dizem as mães: mulheres trabalhadoras e suas experiências. Coimbra, Portugal: Quarteto.

Monteiro, R. (2010). A emergência do feminismo de Estado em Portugal: uma história da criação da Comissão da Condição Feminina. Lisboa, Portugal: CIG.

Monteiro, R., \& Ferreira, V.(2013). Planos para a igualdade de género nas organizações: contributo para o desenho e realização dos diagnósticos organizacionais. Sociedade e Trabalho, 44, 123-136.

Monteiro, R., Agostinho, L. \& Daniel, F. (2015). Um diagnóstico da desigualdade de gênero num município em Portugal: estruturas e represenações. Revista de Administração Pública, 49(2), 423-446. Retrieved from http://dx.doi.org/10.1590/00347612130497

Morgan, D. (1992). Discovering men: critical studies on men and masculinities. London, England: Routledge. 
Nogueira, C. (2001). Feminismo e discurso do género na psicologia social. Psicologia \& Sociedade, 13(1), 107-128.

Ornelas, M. G. R., Matos, F. R. N., Machado, D. Q., \& Mesquita, R. F. (2017). Precariado e género: a trajectória de mulheres portuguesas rumo a uma nova classe em formação. Ámbitos: Revista Internacional de Comunicación, 39, 1-12.

Parker, S. K., \& Griffin, M. A. (2002). What is so bad about a little name-calling? Negative responses of gender harassment for over performance demands and distress. Journal of Occupational Health Psychology, 7(3), 195-210.

Pestana, M. \& Gageiro, J. (2008). Análise de dados para ciências sociais: A complementaridade do SPSS (2 ed.). Lisboa, Portugal: Edições Sílabo.

Peterson, R. (1994). A meta-analysis of Cronbach's coeficiente alpha. Journal of Consumer Research, 21(2), 381-391,

Perista, H. (2002). Manutenção das desigualdades de género nos usos do tempo dedicado às tarefas domésticas e aos filhos. Análise Social, 163, 447-474.

Reskin, B. F., \& Padavic, I. (1994). Women and men at work. Thousand Oaks, CA: Pine Forge Press.

Sealy, R., \& Singh, V. (2010). The importance of role models and demographic context for senior women's work identity development. International Journal of Management Reviews, 12, 284-300.

Smith, P., Crittenden, N., \& Caputi, P. (2012). Measuring women's beliefs about glass ceilings: development of the Career Pathway Survey. Gender in Management: An International Journal, 27(2), 68-80.
Sörlin, A., Ohman, A., Blomstedt, Y., Stenlund, H., \& Lindholm, L. (2011). Measuring the gender gap in organizations. International Journal, 26(4), 275-288.

Spence, J. T., Helmreich, R. L., \& Stapp, J. (1975). Ratings of self and peers on sex role attributes and their relation to self-esteem and conceptions of masculinity and femininity. Journal of Personality and Social Psychology, 32, 29-39.

Swim, J. K., \& Cohen, L. L. (1997). Overt, covert, and subtle sexism. A comparison between the attitudes toward women and modern sexism scales. Psychology of Woman Quarterly, 21(1), 103-118.

Swim, J. K., \& Hyers, L. L. (2009). Sexism. In T. D. Nelson (Ed.), Handbook of prejudice, stereotyping and discrimination (pp. 407-430). New York, NY: Psychology Press.

Torres, A. (2001). Sociologia do casamento. A familia e a questão feminina. Oeiras, Portugal: Celta.

Torres, A., Coelho, B., Jerónimo, P., \& Cabrita, M. (2009, 26 de novembro). Workcare/trabalhar e cuidar na Europa. Retrieved from http:// analiatorres.com/pdf/synopsis_WORKCARE[2].pdf

Wall, K. (Org.). (2005). Famílias em Portugal. Percursos, interacções, redes sociais. Lisboa, Portugal: Imprensa de Ciências Sociais.

Wall, K., Aboim, S., \& Cunha, V. (2010). A vida familiar no masculino: negociando velhas e novas masculinidades. Lisboa, Portugal: Comissão para a Igualdade no Trabalho e no Emprego.

Zawadzki, M., Shields, S., Danube, C., \& Swim, J. (2014). Reducing the endorsement of sexism using experiential learning: the workshop activity for gender equity simulation (WAGES). Psychology of Women Quarterly, 38(1), 75-92. 


\section{Rosa Monteiro}

https://orcid.org/0000-0002-2429-5590

$\mathrm{PhD}$ in Sociology; Professor at Faculty of Economics at Universidade de Coimbra; Researcher at the Center for Social Studies at Universidade de Coimbra. E-mail: monteiro.rosa14@gmail.com

\section{Amélia Filipa Soares Vieira}

https://orcid.org/0000-0002-6492-3037

Master in Human Resources Management and Organizational Behavior at Instituto Superior Miguel Torga.

E-mail: filipavieira_01@hotmail.com

\section{Fernanda Daniel}

https://orcid.org/0000-0002-2202-1123

$\mathrm{PhD}$ in Psychology and Social Work; Assistant Professor at Instituto Superior Miguel Torga; Researcher at the Center for Health Studies and Research at Universidade de Coimbra (CEISUC). E-mail: fernanda-daniel@ismt.pt

\section{Alexandre Gomes da Silva}

https://orcid.org/0000-0001-5163-9670

$\mathrm{PhD}$ in Statistics; Coordinating Professor at Coimbra Business School / ISCAC; Researcher at the Center for Health Studies and Research at Universidade de Coimbra (CEISUC). E-mail: alexmfgs@gmail.com

\section{Fátima Regina Ney Matos}

https://orcid.org/0000-0002-2331-9335

$\mathrm{PhD}$ in Administration; Assistant Professor at Instituto Superior Miguel Torga. E-mail: fneymatos@ismt.pt 